\title{
Effect of ration size on fillet fatty acid composition, phospholipid allostasis and mRNA expression patterns of lipid regulatory genes in gilthead sea bream (Sparus aurata)
}

\author{
Laura Benedito-Palos, Josep A. Calduch-Giner, Gabriel F. Ballester-Lozano and Jaume Pérez-Sánchez* \\ Nutrigenomics and Fish Growth Endocrinology, Instituto de Acuicultura Torre de la Sal, IATS-CSIC, Castellón, Spain \\ (Submitted 8 February 2012 - Final revision received 11 June 2012 - Accepted 11 June 2012 - First published online 2 August 2012)
}

\section{Abstract}

The effect of ration size on muscle fatty acid (FA) composition and mRNA expression levels of key regulatory enzymes of lipid and lipoprotein metabolism have been addressed in juveniles of gilthead sea bream fed a practical diet over the course of an 11-week trial. The experimental setup included three feeding levels: (i) full ration until visual satiety, (ii) $70 \%$ of satiation and (iii) $70 \%$ of satiation with the last 2 weeks at the maintenance ration. Feed restriction reduced lipid content of whole body by $30 \%$ and that of fillet by $50 \%$. In this scenario, the FA composition of fillet TAG was not altered by ration size, whereas that of phospholipids was largely modified with a higher retention of arachidonic acid and DHA. The mRNA transcript levels of lysophosphatidylcholine acyltransferases, phosphatidylethanolamine $N$-methyltransferase and FA desaturase 2 were not regulated by ration size in the present experimental model. In contrast, mRNA levels of stearoyl-CoA desaturases were markedly down-regulated by feed restriction. An opposite trend was found for a muscle-specific lipoprotein lipase, which is exclusive of fish lineage. Several upstream regulatory transcriptions were also assessed, although nutritionally mediated changes in mRNA transcripts were almost reduced to PPAR $\alpha$ and $\beta$, which might act in a counter-regulatory way on lipolysis and lipogenic pathways. This gene expression pattern contributes to the construction of a panel of biomarkers to direct marine fish production towards muscle lean phenotypes with increased retentions of long-chain PUFA.

Key words: Muscle: Lipid metabolism: Lipoprotein lipase: Stearoyl-CoA desaturase

Global fisheries are in decline and farmed fish constitute an increasing proportion of fish in the human food basket ${ }^{(1)}$. Thus, to assure the continuous growth of aquaculture production, the industry is obliged to find suitable alternatives to fish meal and fish oil in fish feeds. Plant products are the obvious choice, but vegetable oils are devoid of $n$ - 3 longchain PUFA (LC-PUFA), and fillet fatty acid (FA) composition of farmed fish points towards a reduction in EPA $(20: 5 n-3)$, docosapentaenoic acid $(22: 5 n-3)$ and DHA (22:6n-3) content. Therefore, the sustainable development of aquaculture and the preservation of health benefits of fish consumption represent a complex trade-off, which is sometimes difficult to reconcile. Indeed, high levels of $n$-3 LC-PUFA are important quality factors in human foods, and there is increasing pressure to include EPA and DHA in the finishing diets of salmonids and freshwater fish, though they do not have specific $n-3$
LC-PUFA requirements ${ }^{(2-4)}$. This reinforces the interest for reliable FA descriptors linking dietary and muscle FA composition. In particular, the association between dietary and fillet FA composition is stronger in oily fish than in lean fish, and direct and highly predictable effects are likely to be found in marine fish due to their limited capacity to convert $\mathrm{C}_{18}$ PUFA of $n-6$ and $n-3$ series to their LC-PUFA ${ }^{(5)}$. According to this, fillet FA composition of gilthead sea bream juveniles is highly predictable for a given class of fish size and adiposity ${ }^{(6)}$, and bivariate regression approaches with FA diet composition and fillet lipid content, as independent variables effectively mirror the year-round fillet FA composition of mature and immature fish ${ }^{(7)}$.

Ration size triggers significant variations in muscle lipid levels of gilthead sea bream ${ }^{(8-11)}$. In salmonids, this outcome has also been broadly described, and concomitant changes in

Abbreviations: EL, endothelial lipase; FA, fatty acid; FADS2, fatty acid desaturase 2; FAME, fatty acid methyl esters; IATS, Institute of Aquaculture Torre de la Sal; LC-PUFA, long-chain PUFA; LPCAT1, lysophosphatidylcholine acyltransferase 1; LPCAT2, lysophosphatidylcholine acyltransferase 2; LPCAT3, lysophosphatidylcholine acyltransferase 3; LPL-like, lipoprotein lipase-like; $L X R \alpha$, liver X receptor $\alpha$; PC, phosphatidylcholine; $P E M T$, phosphatidylethanolamine $N$-methyltransferase; PL, phospholipids; $\mathrm{R}_{100}$ group, full ration until visual satiety; $\mathrm{R}_{70}$ group, $70 \%$ of satiation; $\mathrm{R}_{70-20}$ group, $70 \%$ of satiation with the last 2 weeks at $20 \%$ of satiation level; SCD1a, stearoyl-CoA desaturase $1 \mathrm{a}$; SCD1b, stearoyl-CoA desaturase $1 \mathrm{~b}$; SREBP 1 , sterol regulatory element-binding protein-1; TL, total lipids.

*Corresponding author: Professor J. Pérez-Sánchez, fax + 34 964319509, email jperez@iats.csic.es 
the FA composition of muscle total lipids (TL) have been reported $^{(12,13)}$. Most of these changes in FA signatures have been primarily attributed to switches in the relative proportion of phospholipids (PL) and $\mathrm{TAG}^{(14,15)}$. However, the FA composition of these two lipid fractions is differentially regulated by nutritional and/or environmental conditions due to their different roles in cellular and lipid metabolism ${ }^{(5,16)}$. In fact, the FA composition of TAG usually bears a close resemblance to dietary lipids, whereas that of PL is highly influenced by environmental factors including temperature and osmolarity $^{(17,18)}$, which may be attributed, at least in part, to changes in feeding levels. In this way, the aim of the present study was to evaluate the specific effects of ration size on fillet FA composition and mRNA gene expression of key regulatory enzymes of lipid and lipoprotein metabolism. For that purpose, lipid classes and FA composition of TL, TAG and PL were analysed in juveniles of gilthead sea bream fed from satiety to maintenance ration. In parallel, to gain knowledge of the regulation of lipid metabolism and the nutritional value of flesh, the expression pattern of fourteen selected genes was assessed by means of candidate gene array focused on tissue FA uptake, FA biosynthesis, PL synthesis and remodelling and upstream regulatory transcription factors. This issue was made after exhaustive searches in our gilthead sea bream transcriptome database, which rendered new sequences annotated as lipoprotein lipase-like ( $L P L$-like), lysophosphatidylcholine acyltransferase 1, 2 and 3 (LPCAT1-3), phosphatidylethanolamine $N$-methyltransferase (PEMT), stearoyl-CoA desaturase $1 \mathrm{a}(S C D 1 a)$ and $1 \mathrm{~b}(S C D 1 b)$ and sterol regulatory element-binding protein-1 (SREBP1), and uploaded to GenBank with accession numbers JQ277704-JQ277707, JQ277709, JQ390609 and JQ390612. The study also presented phylogenetic analyses of gene-lineage subfamilies (extracellular TAG lipases and SCD1 enzymes) for which mammalian orthologous genes do not exist yet or remain unclear.

\section{Experimental methods}

\section{Animal care and experimental setup}

Juvenile gilthead sea bream (Sparus aurata L.) of Atlantic origin (Ferme Marine de Douhet) were acclimatised to laboratory conditions for $25 \mathrm{~d}$ before the start of trial (May-July) in the indoor experimental facilities of the Institute of Aquaculture Torre de la Sal (IATS). Following the acclimatisation period, fish of $17 \mathrm{~g}$ initial mean body weight were randomly distributed into 500-litre tanks in triplicate groups of fifty fish each. Fish were fed from May to August (11 weeks) with a commercial diet (D-2 Excel 1P; Skretting) twice per $d$ at three different feeding levels: (i) full ration until visual satiety ( $\mathrm{R}_{100}$ group), (ii) $70 \%$ of satiation ( $\mathrm{R}_{70}$ group) and (iii) $70 \%$ of satiation with the last 2 weeks at the maintenance ration $(20 \%$ of the satiation level; $\mathrm{R}_{70-20}$ group). Maintenance ration was conveniently calculated according to fish size and temperature $\left(23-25^{\circ} \mathrm{C}\right)$ at this last stage of the experimental trial. The FA composition of the diet is reported in Table 1.

The trial was conducted under the natural photoperiod and temperature conditions at IATS latitude $\left(40^{\circ} 5 \mathrm{~N} ; 0^{\circ} 10 \mathrm{E}\right)$. Water
Table 1. Diet fatty acid (FA) composition (\% total FA methyl esters)

\begin{tabular}{lc}
\hline FA $(\%)$ & Diet \\
\hline $14: 0$ & $5 \cdot 01$ \\
$15: 0$ & $0 \cdot 11$ \\
$16: 0$ & $17 \cdot 57$ \\
$16: 1 n-7$ & $4 \cdot 81$ \\
$16: 2$ & $0 \cdot 77$ \\
$16: 3$ & $0 \cdot 17$ \\
$16: 4$ & $1 \cdot 17$ \\
$17: 0$ & $0 \cdot 86$ \\
$18: 0$ & $4 \cdot 14$ \\
$18: 1 n-9$ & $15 \cdot 55$ \\
$18: 1 n-7$ & $2 \cdot 90$ \\
$18: 2 n-6$ & $21 \cdot 4$ \\
$18: 3 n-6$ & $0 \cdot 19$ \\
$18: 3 n-3$ & $2 \cdot 38$ \\
$18: 4 n-3$ & $0 \cdot 89$ \\
$20: 0$ & $0 \cdot 26$ \\
$20: 1 n-7$ & $0 \cdot 23$ \\
$20: 1 n-9$ & $1 \cdot 17$ \\
$20: 2 n-6$ & $0 \cdot 13$ \\
$20: 3 n-6$ & $0 \cdot 14$ \\
$20: 3 n-3$ & $0 \cdot 05$ \\
$20: 4 n-6$ & $0 \cdot 61$ \\
$20: 4 n-3$ & $0 \cdot 34$ \\
$20: 5 n-3$ & $7 \cdot 53$ \\
$22: 0$ & $0 \cdot 23$ \\
$22: 1 n-9$ & $0 \cdot 29$ \\
$22: 1 n-11$ & $1 \cdot 0$ \\
$22: 5 n-3$ & $0 \cdot 9$ \\
$22: 6 n-3$ & $4 \cdot 5$ \\
\hline & \\
\hline
\end{tabular}

flow was 20 litres/min and oxygen content of water effluents was always higher than $85 \%$ saturation. At the end of the trial period and following overnight fasting, nine randomly selected fish per dietary treatment were anaesthetised with 3-aminobenzoic acid ethyl ester (MS-222, $100 \mu \mathrm{g} / \mathrm{ml}$ ). The entire fillet from fish left side (denuded from skin) was taken, vacuum packed and stored at $-80^{\circ} \mathrm{C}$ until lipid analyses. A representative portion of the skeletal muscle (dorsal white muscle) from the right side of the fish was taken under RNAse-free conditions, frozen with liquid $\mathrm{N}_{2}$ and stored at $-80^{\circ} \mathrm{C}$ until gene expression analyses. Nine aditional fish per dietary treatment were used for whole-body composition analyses.

All procedures were carried out according to the national (IATS-CSIC Review Board) and present EU legislation on the handling of experimental animals.

\section{Lipid analyses}

Fillets and specimens for whole-body analyses were ground and small aliquots were dried to estimate the moisture content. The moisture content was determined by drying in an oven at $105^{\circ} \mathrm{C}$ for $24 \mathrm{~h}$. The remaining samples were freezedried and the TL content was determined gravimetrically using the Soxhlet 4001046 Auto extraction apparatus (Selecta) with $50 \mathrm{ml}$ diethyl ether at $120^{\circ} \mathrm{C}$, according to the manufacturer's instructions.

Fillet lipids for analyses of FA and lipid classes were extracted by the method of Folch et $a l^{(19)}$, with 
chloroform-methanol (2:1) containing $\quad 0 \cdot 01 \%$ butylated hydroxytoluene as antioxidant. The analysis of lipid classes was performed by high-performance TLC using a onedimensional double development, as described by Olsen \& Henderson $^{(20)}$. Briefly, TL were separated on TLC plates $(10 \times 10 \mathrm{~cm}$, silica gel $(200 \mu \mathrm{m})$; Merck $)$ using methyl acetate-isopropanol-chloroform-methanol-0.25\% aqueous potassium chloride (25:25:25:10:9, by vol.) and hexane-diethyl ether-acetic acid (85:15:1.5, by vol.) as developing solvent mixtures for PL and neutral lipids, respectively. The separated lipid fractions were charred for $10 \mathrm{~min}$ at $160^{\circ} \mathrm{C}$ after spraying the plate with $3 \%(\mathrm{w} / \mathrm{v})$ cupric acetate in $8 \%(\mathrm{v} / \mathrm{v})$ phosphoric $\operatorname{acid}^{(21)}$ and were quantified by calibrated scanning densitometry (Bio-Rad GS670 Imaging densitometer; Bio-Rad). The quantity of each lipid class was expressed on wet matter basis.

The FA from TL were fractionated by TLC (Silica gel G 60, $20 \times 20 \mathrm{~cm}$ glass plates; Merck), using hexane-diethyl etheracetic acid (85:15:1.5, by vol.) as a solvent system. The PL bands were scraped and extracted with chloroform-methanol $(2: 1, \mathrm{v} / \mathrm{v})$ containing $0.01 \%$ butylated hydroxytoluene. The TAG were scraped and extracted with hexane-diethyl ether $(1: 1, \mathrm{v} / \mathrm{v})$. After the addition of non-adecanoic FA (Sigma) as internal standard, fractions of TL, TAG and PL were subjected to acid-catalysed transmethylation for $16 \mathrm{~h}$ at $50^{\circ} \mathrm{C}$ using toluene and $1 \%(\mathrm{v} / \mathrm{v}) \mathrm{H}_{2} \mathrm{SO}_{4}$ in methanol ${ }^{(22)}$. The FA methyl esters

Table 2. Forward and reverse primers for quantitative real-time PCR
(FAME) were extracted with hexane-diethyl ether $(1: 1, \mathrm{v} / \mathrm{v})$, and those derived from TL were purified by TLC using hexane-diethyl ether-acetic acid (85:15:1.5, by vol.) as a solvent system. The FAME were then analysed with a gas chromatograph (GC 8000 Series; Fisons Instruments) equipped with a fused-silica $30 \mathrm{~m} \times 0.25 \mathrm{~mm}$ open tubular column (film thickness: 0.25 $\mu \mathrm{m}$; Tracer, TR-WAX; Teknokroma) and a cold on-column injection system. Helium was used as a carrier gas and temperature programming was from 50 to $180^{\circ} \mathrm{C}$ at $40^{\circ} \mathrm{C} /$ min and then to $220^{\circ} \mathrm{C}$ at $3^{\circ} \mathrm{C} / \mathrm{min}$. Peaks were recorded in a personal computer using a software package (Azur, Datalys). Individual FAME were identified by reference to well-characterised fish oil standards in the analysed sample.

Marinol (sardine oil) from the Fishing Industry Research Institute (Rosebank) and FAME 37 from Supelco were used as fish oil standards. Butylated hydroxytoluene and internal standard (19:0) were obtained from Sigma-Aldrich. All lipid solvents were of HPLC grade and were obtained from Merck.

\section{Gene expression analysis}

For the two extreme groups $\left(\mathrm{R}_{100}\right.$ and $\left.\mathrm{R}_{70-20}\right)$, total RNA from skeletal muscle was extracted using the ABI PRISM ${ }^{\mathrm{TM}} 6100$ Nucleic Acid PrepStation (Applied Biosystems) with a DNAse step. The RNA yield was 30-50 $\mu \mathrm{g}$, with absorbance measures

\begin{tabular}{|c|c|c|c|c|}
\hline \multirow[b]{2}{*}{ Gene } & \multirow[b]{2}{*}{ Symbol } & \multirow{2}{*}{$\begin{array}{l}\text { Accession } \\
\text { number }\end{array}$} & \multicolumn{2}{|c|}{ Primer sequence $\left(5^{\prime}-3^{\prime}\right)$} \\
\hline & & & Forward & Reverse \\
\hline Fatty acid desaturase $2^{*}$ & FADS2 & AY055749 & $\begin{array}{l}\text { GCA GGC GGA GAG CGA } \\
\text { CGG TCT GTT CC }\end{array}$ & $\begin{array}{l}\text { AGC AGG ATG TGA CCC } \\
\text { AGG TGG AGG CAG AAG }\end{array}$ \\
\hline Lipoprotein lipase $\dagger$ & $L P L$ & AY495672 & $\begin{array}{l}\text { CGT TGC CAA GTT TGT } \\
\text { GAC CTG }\end{array}$ & $\begin{array}{l}\text { AGG GTG TTC TGG TTG } \\
\text { TCT GC }\end{array}$ \\
\hline Lipoprotein lipase-like $†$ & LPL-like & JQ390609 & $\begin{array}{l}\text { CAG AGA TGG AGC CGT } \\
\text { CAC TCA C }\end{array}$ & $\begin{array}{l}\text { TCT GTC ACC AGC AGG } \\
\text { AAC GAA TG }\end{array}$ \\
\hline Liver $X$ receptor $\alpha \ddagger$ & $L X R \alpha$ & FJ502320 & $\begin{array}{l}\text { GCA CTT CGC CTC CAG } \\
\text { GAC AAG }\end{array}$ & $\begin{array}{l}\text { CAG TCT TCA CAC AGC } \\
\text { CAC ATC AGG }\end{array}$ \\
\hline Lysophosphatidylcholine acyltransferase $1 \S$ & LPCAT1 & JQ390612 & $\begin{array}{l}\text { CGT GAT AGC CTT ATC } \\
\text { TGT CGT ATG C }\end{array}$ & $\begin{array}{l}\text { CCG TCC TCC TCT GCC } \\
\text { TCA A }\end{array}$ \\
\hline Lysophosphatidylcholine acyltransferase $2 \S$ & LPCAT2 & JQ277705 & $\begin{array}{l}\text { GAC TGC CGC CTG ATG } \\
\text { ATC TC }\end{array}$ & $\begin{array}{l}\text { ATG GTG ATG CGT CCT } \\
\text { CCT TTA C }\end{array}$ \\
\hline Lysophosphatidylcholine acyltransferase $3 \S$ & LPCAT3 & JQ277706 & $\begin{array}{l}\text { TGA CGG CGG GCA GGA } \\
\text { ACC ATC }\end{array}$ & $\begin{array}{c}\text { CCC ACC AGG AAG CCT } \\
\text { CCA TAG AAG TAG }\end{array}$ \\
\hline Peroxisome proliferator-activated receptor $\alpha \ddagger$ & $P P A R \alpha$ & AY590299 & $\begin{array}{l}\text { TCT CTT CAG CCC ACC } \\
\text { ATC CC }\end{array}$ & $\begin{array}{l}\text { ATC CCA GCG TGT CGT } \\
\text { CTC C }\end{array}$ \\
\hline Peroxisome proliferator-activated receptor $\beta \ddagger$ & $P P A R \beta$ & AY590301 & $\begin{array}{l}\text { AGG CGA GGG AGA GTG } \\
\text { AGG ATG AGG AG }\end{array}$ & $\begin{array}{l}\text { CTG TTC TGA AAG CGA } \\
\text { GGG TGA CGA TGT TTG }\end{array}$ \\
\hline Peroxisome proliferator-activated receptor $\gamma \neq$ & PPAR $\gamma$ & AY590304 & $\begin{array}{l}\text { CGC CGT GGA CCT GTC } \\
\text { AGA GC }\end{array}$ & $\begin{array}{l}\text { GGA ATG GAT GGA GGA } \\
\text { GGA GGA GAT GG }\end{array}$ \\
\hline Phosphatidylethanolamine $N$-methyltransferase $\S$ & PEMT & JQ277707 & $\begin{array}{l}\text { TTG GTG CCA GTC CTG } \\
\text { TTG GTC TC }\end{array}$ & $\begin{array}{l}\text { TGA TAG ATC AGT CCA } \\
\text { GTG AAT GGT CCT TC }\end{array}$ \\
\hline Stearoyl-CoA desaturase $1 a^{*}$ & SCD1a & JQ277703 & $\begin{array}{l}\text { CGG AGG CGG AGG CGT } \\
\text { TGG AGA AGA AG }\end{array}$ & $\begin{array}{r}\text { AGG GAG ACG GCG TAC } \\
\text { AGG GCA CCT ATA TG }\end{array}$ \\
\hline Stearoyl-CoA desaturase $1 b^{*}$ & $S C D 1 b$ & JQ277704 & $\begin{array}{l}\text { GCT CAA TCT CAC CAC } \\
\text { CGC CTT CAT AG }\end{array}$ & $\begin{array}{l}\text { GCT GCC GTC GCC CGT } \\
\text { TCT CTG }\end{array}$ \\
\hline Sterol regulatory element-binding protein-1 $1 \ddagger$ & SREBP1 & JQ277709 & $\begin{array}{l}\text { AGG GCT GAC CAC AAC } \\
\text { GTC TCC TCT CC }\end{array}$ & $\begin{array}{l}\text { GCT GTA CGT GGG ATG } \\
\text { TGA TGG TTT GGG }\end{array}$ \\
\hline$\beta$-Actin & ACTB & X89920 & $\begin{array}{l}\text { TCC TGC GGA ATC CAT } \\
\text { GAG A }\end{array}$ & $\begin{array}{l}\text { GAC GTC GCA CTT CAT } \\
\text { GAT GCT }\end{array}$ \\
\hline
\end{tabular}

${ }^{*}$ Fatty acid desaturases.

† Key enzymes on tissue fatty acid uptake.

$\ddagger$ Transcription factors.

$\S$ Enzymes involved in phospholipid synthesis and remodelling. 
Table 3. Characteristics of assembled sequences according to basic local alignment search tool (BLAST) searches

\begin{tabular}{lrccccc}
\hline Contig(s) & $F^{*}$ & Size $(\mathrm{nt})$ & Annotation† & Best match $¥$ & $E \S$ & CDS \\
\hline C2_29860 & 42 & 2518 & LPL-like & BAB20996 & 0.0 & $28-1515$ \\
C2_14455 & 24 & 1862 & LPCAT1 & XP_003443759 & $0 \cdot 0$ & $369->1862$ \\
C2_8782 & 55 & 2091 & LPCAT2 & XP_003437708 & $3 \times 10^{-157}$ & $<1-914$ \\
C2_13645 & 23 & 1441 & LPCAT3 & XP_003450693 & $0 \cdot 0$ & $<1-1296$ \\
C2_36050 & 6 & 1571 & PEMT & ACl68830 & $9 \times 10^{-118}$ & $129-830$ \\
C2_81189 & 3 & 367 & SREBP1 & CAG03157 & $9 \times 10^{-12}$ & $<1->367$ \\
C2_3937 & 99 & 1382 & SCD1a & CBN81527 & 0.0 & $156-1163$ \\
C2_5624 & 120 & 1665 & SCD1b & CBM40644 & $0 \cdot 0$ & $148-1155$ \\
\hline
\end{tabular}

nt, Nucleotides; CDS, codifying domain sequence.

* Number of sequences.

† Gene identity determined through BLAST searches.

$\ddagger$ Best BLAST-X protein sequence match.

$\S$ Expectation value.

$\left(A_{260 / 280}\right)$ of $1 \cdot 9-2 \cdot 1$. Reverse transcription of 500-ng total RNA was performed with random decamers using the HighCapacity cDNA Archive Kit (Applied Biosystems). Quantitative real-time PCR was performed with an iCycler IQ Real-time Detection System (Bio-Rad), as described elsewhere ${ }^{(23)}$. Briefly, diluted reverse transcription reactions were conveniently used for PCR reactions in $25 \mu \mathrm{l}$ volume, in combination with a SYBR Green Master Mix (Bio-Rad). Specific primers for target genes and $\beta$-actin (housekeeping gene) were used at a final concentration of $0.9 \mu \mathrm{m}$ (Table 2). The $\Delta \Delta C_{\mathrm{t}}$ method $^{(24)}$ was used for the normalisation procedure, and expression values were referred to PEMT as reference gene. The set of primers for $L P L$, liver X receptor $\alpha(L X R \alpha)$ and PPAR $\alpha, P P A R \beta$ and PPAR $\gamma$ were the same as previously used $^{(25,26)}$. New sets of primers were designed for FA desaturase 2 (FADS2) and additional sequences were generated following the update (November 2011) of the IATS complementary DNA gilthead sea bream database (http://www. sigenae.org/iats). These new sequences were submitted to GenBank as partial (LPCAT1, LPCAT2, LPCAT3, SREBP1) or complete (LPL-like, PEMT, SCD1a, SCD1b) codifying sequences (Table 3). Of note, the best hit for $L P L$-like is a red sea bream sequence (AB054063) annotated as LPL2 by Oku et $a l .{ }^{(27)}$. SCD1a (JQ277703) and SCD1b (JQ277704) sequences were annotated according to the revised nomenclature for the stearoyl-CoA desaturase family ${ }^{(28)}$.

\section{Phylogenetic analysis}

Phylogenetic analysis was carried out on the basis of amino acid differences (p-distance) with the unweighted pair group method with arithmetic mean algorithm (pairwise deletion) in MEGA software (version 5.0; www.megasoftware.net). A total of thirty-seven sequences from fourteen species were included in the phylogenetic analyses of SCD1 enzymes and extracellular TAG lipases. Reliability of phylogenetic trees was assessed by bootstrapping using 1000 bootstrap replications.

\section{Statistical analysis}

Data on growth performance and lipid composition analyses were analysed by one-way ANOVA followed by the StudentNewman-Keuls test $(P<0.05)$. Data on gene expression were analysed by Student's $t$ test. All analyses were performed using the SPSS 17.0 program (SPSS, Inc.).

\section{Results}

\section{Growth performance and lipid analyses}

Data on body weight are shown in Fig. 1 . Fish of the $R_{100}$ group grew from $17(\mathrm{SD} 0.12)$ to $72(\mathrm{SD} 0.34) \mathrm{g}$, with a feed efficiency (wet weight gain/dry feed intake) of 0.89 (SD 0.07). The $30 \%$ feed restriction ( $\mathrm{R}_{70}$ group) had a lesser final body weight (60 (SD 0.02) g) with a slight, but statistically significant $(P<0.05)$, improvement in feed efficiency $(0.97$ (SD 0.02)). In the $\mathrm{R}_{70-20}$ group, the feed intake was adjusted in the last 2 weeks to maintenance ration, and the final body weight (48.6 (SD 0.22) g) was accordingly lower. For more details on growth and bioenergetics, see Bermejo-Nogales et al. ${ }^{(29)}$.

As shown in Table 4, whole-body lipid content in wet matter basis was significantly lower in $\mathrm{R}_{70-20}$ group $(8.8 \%)$ in comparison to the other two experimental groups $(12 \cdot 3-11 \cdot 7 \%)$. In parallel, the water content increased significantly and progressively with the reduction of ration size from $65.3 \%$ in the $\mathrm{R}_{100}$ group to $69.8 \%$ in the $\mathrm{R}_{70-20}$. Similar trends were found for moisture and lipid content in fillet

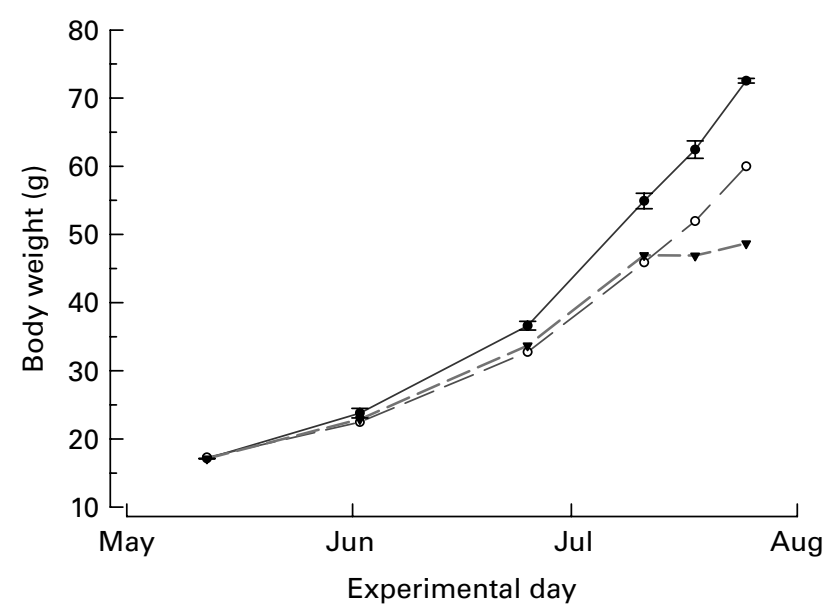

Fig. 1. Body weight over the course of the growth trial of fish fed a practical diet with different feeding levels. $\longrightarrow$, Full ration until visual satiety $\left(R_{100}\right)$; - o- - , 70\% of satiation $\left(\mathrm{R}_{70}\right)$; - $-\mathbf{-}-, 70 \%$ of satiation with the last 2 weeks at $20 \%$ of satiation level $\left(R_{70-20}\right)$. 
Table 4. Fillet lipid class composition (\% wet weight), moisture (\%) and lipid content (\% fillet wet weight) of whole body and fillets of fish fed at three different feeding levels (Mean values and standard deviations, $n$ 9)

\begin{tabular}{|c|c|c|c|c|c|c|}
\hline & \multicolumn{2}{|c|}{$\mathrm{R}_{100}$} & \multicolumn{2}{|c|}{$\mathrm{R}_{70}$} & \multicolumn{2}{|c|}{$\mathrm{R}_{70-20}$} \\
\hline & Mean & SD & Mean & SD & Mean & SD \\
\hline Whole-body moisture & $65 \cdot 34^{\mathrm{a}}$ & 0.17 & $66 \cdot 53^{\mathrm{b}}$ & 0.31 & $69 \cdot 80^{c}$ & 0.42 \\
\hline Whole-body fat & $12 \cdot 31^{\mathrm{a}}$ & 0.38 & $11.68^{\mathrm{a}}$ & 0.39 & $8 \cdot 79^{\mathrm{b}}$ & 0.28 \\
\hline Fillet moisture & $72 \cdot 44^{\mathrm{a}}$ & 0.36 & $74.75^{\mathrm{b}}$ & 0.44 & $75 \cdot 51^{\mathrm{b}}$ & 0.53 \\
\hline Fillet fat & $6 \cdot 50^{\mathrm{a}}$ & 0.63 & $4.49^{b}$ & 0.33 & $3 \cdot 36^{c}$ & 0.24 \\
\hline \multicolumn{7}{|l|}{ Fillet lipid class } \\
\hline CE & 0.25 & 0.13 & 0.22 & 0.13 & 0.18 & 0.15 \\
\hline TAG & $4.00^{\mathrm{a}}$ & $1 \cdot 20$ & $2 \cdot 16^{\mathrm{b}}$ & 0.76 & $2 \cdot 37^{\mathrm{b}}$ & 0.89 \\
\hline NEFA & $0 \cdot 11^{\mathrm{a}}$ & 0.05 & $0.07^{a, b}$ & 0.06 & $0.02^{b}$ & 0.01 \\
\hline $\mathrm{COL}$ & $0.53^{\mathrm{a}}$ & 0.09 & $0.37^{\mathrm{b}}$ & 0.11 & $0.40^{\mathrm{b}}$ & 0.09 \\
\hline DG & $0 \cdot 15^{\mathrm{a}}$ & 0.05 & $0.08^{\mathrm{b}}$ & 0.05 & $0.07^{b}$ & 0.03 \\
\hline MG & 0.06 & 0.01 & 0.04 & 0.01 & 0.04 & 0.02 \\
\hline $\mathrm{PE}$ & $0.31^{a}$ & 0.05 & $0.25^{\mathrm{b}}$ & 0.06 & $0.24^{b}$ & 0.04 \\
\hline $\mathrm{PA} / \mathrm{CL}$ & 0.08 & 0.03 & 0.07 & 0.02 & 0.06 & 0.01 \\
\hline PI & 0.08 & 0.02 & 0.07 & 0.02 & 0.07 & 0.01 \\
\hline PS & 0.04 & 0.01 & 0.04 & 0.01 & 0.04 & 0.01 \\
\hline $\mathrm{PC}$ & 0.48 & 0.07 & 0.41 & 0.10 & 0.41 & 0.09 \\
\hline SM & 0.05 & 0.04 & 0.03 & 0.02 & 0.03 & 0.02 \\
\hline Total NL & $5 \cdot 10^{\mathrm{a}}$ & 0.47 & $2.94^{b}$ & 0.34 & $3.08^{b}$ & 0.38 \\
\hline Total PL & 1.04 & 0.06 & 0.87 & 0.07 & 0.85 & 0.06 \\
\hline
\end{tabular}

$R_{100}$, full ration until visual satiety; $R_{70}, 70 \%$ of satiation; $R_{70-20}, 70 \%$ of satiation with the last 2 weeks at $20 \%$ of satiation level; CE, cholesteryl esters; COL, cholesterol; DG, diacylglycerols; MG, monoacylglycerols; $P E$, phosphatidyl ethanolamine; $P A / C L$, phosphatidic acid/cardiolipin; PI, phosphatidyl inositol; PS, phosphatidyl serine; PC, phosphatidyl choline; SM, sphingomyelin; $\mathrm{NL}$, neutral lipids; PL, polar lipids.

$\mathrm{a}, \mathrm{b}, \mathrm{c}$ Mean values with unlike superscript letters were significantly different $(P<0.05)$.

samples, but in this case, the reduction of lipid content was higher, changing progressively and significantly from $6.5 \%$ in the $R_{100}$ group to $3.3 \%$ in the $R_{70-20}$. The reduction of ration size also affected the lipid class composition, mainly due to changes in neutral lipids, with a $5 \cdot 1 \%$ reduction in the $\mathrm{R}_{100}$ group and $2 \cdot 9-3 \cdot 1 \%$ in the other two experimental groups. A slight but significant reduction of phosphatidylethanolamine was found with the intermediate and severe reduction of ration size, but significant changes were not found for PL, considered globally as the sum of phosphatidylethanolamine, phosphatidylcholine (PC) and other minor polar lipid fractions.

The changes in ration size modified the fillet FA composition of TL (Table 5), with a statistically significant reduction in \%FAME of $14: 0,16: 1 n-7,18: 1 n-9,18: 2 n-6,18: 3 n-6$ and $18: 3 n-3$. This trend was the opposite for DHA, which achieved a maximum of $8.4 \%$ in the $\mathrm{R}_{70-20}$ group and lower levels $(7 \cdot 2-7 \cdot 3 \%)$ in $R_{70}$ and $R_{100}$ groups.

Experimental data evidenced minor changes in the FA composition of TAG (Table 6). Of note, only four FA $(16: 4,20: 1 n-9,22: 1 n-9,22: 6 n-3)$ varied significantly and progressively with the reduction of ration size. This contrasted with the observations made in PL, where a high number of FA, including $14: 0,17: 0$, monoenes $(16: 1 n-7,18: 1 n-9,18: 1 n-7$, $20: 1 n-9)$ and most PUFA of $n-3(18: 3 n-3,18: 4 n-3,20: 4 n-3$, $20: 5 n-3)$ and $n-6$ series (18:2n-6, 18:3n-6, 20:2n-6, 20:3n-6) decreased significantly in $\mathrm{R}_{70-20}$ fish. This trend was opposite for 20:4n-6 (arachidonic acid) and DHA, which varied between two extreme groups from 2.4 to $2 \cdot 2 \%$ and from 23.7 to $19 \cdot 2 \%$, respectively.

\section{Phylogenetic and gene expression analyses}

Phylogenetic analysis of the endogenous extracellular TAG lipase family was performed with representative sequences of reptiles, mammals and fish, and the resulting tree revealed three major nodes of LPL, hepatic lipase and endothelial lipase (EL), according to the present hierarchy of vertebrates (Fig. 2(a)). A fourth node, closely related to LPL but exclusive of fish lineage, was identified. This additional node, named LPL-like, is presently represented by LPL sequences from zebrafish, tuna and sparid fish (red sea bream and gilthead sea bream).

As shown in Fig. 2(b), phylogenetic analysis of SCD1 sequences from modern teleost fish identified two major clades of SCD1a and SCD1b isoforms, according to the present hierarchy of teleosts. The analysis was carried out with sequences derived from model and non-model fish species, including those derived from gilthead sea bream. As expected, representative mammalian SCD1 sequences are fitted as outgroup when they are included in the analysis.

The muscle gene expression profile of the two extreme groups is shown in Fig. 3. Irrespective of experimental condition, the highest mRNA levels for the analysed lipid enzymes were encountered for SCD1b, LPL-like and LPCAT3, whereas lower levels were found for FADS 2 and then for PEMT and SCD1a (Fig. 3(a)). As concerns transcriptional regulatory factors (Fig. 3(b)), the highest mRNA expression was found for SREBP1 and the lowest for $L X R \alpha$, with intermediate values for PPAR isoforms. When the gene expression pattern was compared between $\mathrm{R}_{100}$ and $\mathrm{R}_{70-20}$ groups, no differences were found at the level of PEMT, LPCAT1, LPCAT2, LPCAT3, 
Table 5. Fatty acid (FA) composition (\% total FA methyl esters) of total lipids from fillets of fish fed different feeding levels: full ration until visual satiety $\left(R_{100}\right.$ group), $70 \%$ of satiation $\left(R_{70}\right)$ and $70 \%$ of satiation with the last 2 weeks at $20 \%$ of satiation level $\left(R_{70-20}\right)$

(Mean values and standard deviations, $n$ 9)

\begin{tabular}{|c|c|c|c|c|c|c|}
\hline \multirow[b]{2}{*}{ FA (\%) } & \multicolumn{2}{|c|}{$\mathrm{R}_{100}$} & \multicolumn{2}{|c|}{$\mathrm{R}_{70}$} & \multicolumn{2}{|c|}{$\mathrm{R}_{70-20}$} \\
\hline & Mean & SD & Mean & SD & Mean & SD \\
\hline $14: 0$ & $3 \cdot 30^{a, b}$ & 0.09 & $3.50^{\mathrm{a}}$ & 0.26 & $3 \cdot 16^{b}$ & 0.30 \\
\hline $15: 0$ & 0.12 & 0.02 & $0 \cdot 12$ & 0.02 & 0.11 & 0.02 \\
\hline $16: 0$ & $16 \cdot 65$ & 1.00 & 17.55 & 1.05 & $15 \cdot 23$ & 1.54 \\
\hline $16: 1 n-7$ & $5 \cdot 59^{b}$ & 0.09 & $5 \cdot 37^{a, b}$ & 0.32 & $5 \cdot 21^{a}$ & 0.32 \\
\hline $16: 2$ & $0.71^{\mathrm{a}}$ & 0.02 & $0.59^{b}$ & 0.05 & $0.66^{a, b}$ & 0.07 \\
\hline $16: 3$ & $0.79^{\mathrm{a}}$ & 0.03 & $0.72^{\mathrm{b}}$ & 0.04 & $0.73^{b}$ & 0.05 \\
\hline $16: 4$ & $0.51^{\mathrm{a}}$ & 0.07 & $0.38^{\mathrm{b}}$ & 0.10 & $0.45^{\mathrm{a}}$ & 0.06 \\
\hline $17: 0$ & $0.36^{a}$ & 0.01 & $0.40^{\mathrm{b}}$ & 0.02 & $0.35^{\mathrm{a}}$ & 0.03 \\
\hline $18: 0$ & 4.40 & 0.23 & 4.79 & 0.38 & $4 \cdot 36$ & 0.49 \\
\hline $18: 1 n-9$ & $18 \cdot 27^{\mathrm{a}}$ & 0.68 & $17 \cdot 41^{\mathrm{b}}$ & 1.04 & $16 \cdot 83^{b}$ & 0.89 \\
\hline $18: 1 n-7$ & $2 \cdot 89$ & 0.07 & $2 \cdot 83$ & 0.16 & $2 \cdot 74$ & 0.19 \\
\hline $18: 2 n-6$ & $18 \cdot 75^{a}$ & 0.20 & $17 \cdot 48^{\mathrm{b}}$ & 0.92 & $16 \cdot 98^{\mathrm{b}}$ & $1 \cdot 16$ \\
\hline $18: 3 n-6$ & $0.24^{\mathrm{a}}$ & 0.01 & $0.21^{\mathrm{b}}$ & 0.01 & $0.21^{\mathrm{b}}$ & 0.02 \\
\hline $18: 3 n-3$ & $2.05^{\mathrm{a}}$ & 0.02 & $1.78^{\mathrm{b}}$ & 0.10 & $1 \cdot 80^{\mathrm{b}}$ & 0.13 \\
\hline $18: 4 n-3$ & $0.91^{a}$ & 0.15 & $0.74^{b}$ & 0.07 & $0.84^{a, b}$ & 0.07 \\
\hline $20: 1 n-7$ & 0.16 & 0.03 & 0.15 & 0.02 & 0.14 & 0.02 \\
\hline $20: 1 n-9$ & 1.34 & 0.02 & 1.34 & 0.09 & 1.35 & 0.13 \\
\hline $20: 2 n-6$ & 0.50 & 0.10 & 0.48 & 0.06 & 0.49 & 0.04 \\
\hline $20: 3 n-6$ & $0.37^{\mathrm{a}}$ & 0.06 & $0.27^{b}$ & 0.11 & $0.30^{a, b}$ & 0.04 \\
\hline $20: 3 n-3$ & $0.09^{a}$ & 0.01 & $0.07^{b}$ & 0.02 & $0.08^{a, b}$ & 0.01 \\
\hline $20: 4 n-6$ & 0.68 & 0.05 & 0.66 & 0.17 & 0.75 & 0.09 \\
\hline $20: 4 n-3$ & 0.52 & 0.02 & 0.42 & 0.14 & 0.49 & 0.03 \\
\hline $20: 5 n-3$ & 6.48 & 0.34 & 5.96 & 0.37 & $6 \cdot 34$ & 0.49 \\
\hline $22: 1 n-9$ & 0.28 & 0.01 & 0.26 & 0.05 & 0.28 & 0.03 \\
\hline $22: 1 n-11$ & 0.84 & 0.03 & 0.87 & 0.11 & 0.89 & 0.08 \\
\hline $22: 5 n-3$ & $2 \cdot 40$ & 0.15 & 2.05 & 0.13 & $2 \cdot 33$ & 0.20 \\
\hline $22: 6 n-3$ & $7 \cdot 33^{a}$ & 0.56 & $7 \cdot 25^{a}$ & 0.83 & $8.45^{\mathrm{b}}$ & 1.07 \\
\hline
\end{tabular}

${ }_{\mathrm{a}, \mathrm{b}}$ Mean values within experimental groups with unlike superscript letters were significantly different $(P<0.05)$.

$L P L, F A D S 2, F A S, P P A R \gamma, L X R \alpha$ and SREBP1. In contrast, the expression of $L P L$-like, PPAR $\alpha$ and PPAR $\beta$ was significantly up-regulated in the $\mathrm{R}_{70-20}$ group, whereas that of SCD1a and $S C D 1 b$ was significantly down-regulated. When data for a given gene in $\mathrm{R}_{70-20}$ fish were referred to $\mathrm{R}_{100}$ fish, the foldchanges for the up-regulated genes were 1.93, 2.02 and 1.92 for $L P L$-like, PPAR $\alpha$ and PPAR $\beta$, respectively. In the case of down-regulated genes, the fold-changes were $0 \cdot 17$ for SCD1a and 0.62 for SCD1b.

\section{Discussion}

Muscle lipid content has a considerable interest for the farm animal industry, as it strongly affects meat quality ${ }^{(30)}$. Hence, dietary manipulation and genetic selection are presently the main tools used to manage muscle fat content in farmed fish ${ }^{(31-33)}$. Different flesh lipid deposition rates also modify the nutritional value of the end product and, thereby, the present study was focused on the effect of ration size on the fillet FA profiles of gilthead sea bream. From the present results, it is conclusive that the reduction of ration size entailed the decrease of lipid content of whole body and fillet, which was accompanied by a decrease of water content, whereas that of protein and ash remained unchanged (data not shown). The decrease of TL was closely associated to the reduction of neutral lipid content, whereas the amount of polar lipids remained unchanged. Regarding FA profiles, our previous gilthead sea bream study highlights the fact that the fillet FA composition of PL remains mostly unaltered when the theoretical requirements of essential FA are met through $\operatorname{diet}^{(34)}$. Moreover, the robustness of PL is apparently greater in tissues with higher dietary requirements in essential $\mathrm{FA}^{(35)}$. This contrasts with the plasticity of TAG, which closely resembles the FA composition of the diet in a wide range of cultured fish, including gilthead sea bream ${ }^{(35)}$, European sea bass $^{(36)}$, Atlantic cod ${ }^{(37)}$, turbot ${ }^{(38)}$, Atlantic salmon ${ }^{(39)}$, sunshine bass ${ }^{(40)}$, pike perch ${ }^{(41)}$ and arctic charr ${ }^{(42)}$. However, ration size and dietary lipid sources affect the FA composition of neutral and polar lipids differentially, at least when evaluated in juvenile gilthead sea bream fed at maintenance ration for 2 weeks in the summer growing period. Indeed, the fillet FA profile of TAG remained mostly unaltered with the reduction in ration size and muscle lipid depots, whereas polar lipids exhibited significant changes that mostly affected arachidonic acid and DHA in the case of LC-PUFA. Earlier studies in rainbow trout ${ }^{(14)}$ and chinook salmon ${ }^{(15)}$ do not support this finding, and the authors concluded that the effect of ration on muscle FA composition is primarily due to changes in the relative levels of PL and TAG. However, in the present study, changes in the PL profile contribute directly and/or indirectly to the lean phenotype of $R_{70-20}$. It is not easy to explain the differences in lipid metabolism of these apparent fish species, but it should be stressed that the overall literature strongly supports the allostatic regulation of PL in response to different stimuli ${ }^{(17)}$.

Several studies in cultured fish with varying feeding levels $^{(43,44)}$ and diet composition ${ }^{(3,45-48)}$ denote that both arachidonic acid and DHA can be selectively retained to meet the requirements for tissue membrane FA and function. It has also been observed that lean strains of Atlantic salmon accumulate $n$-3 LC-PUFA more rapidly that fat fish ${ }^{(33)}$. For instance, intervention studies in human subjects and rodents highlight the fact that hypoenergetic diets facilitate the unsaturation of skeletal muscle PL in association with improved insulin sensitivity ${ }^{(49-52)}$. This agrees with the observation that the Pima Indians, a population with a high prevalence of diabetes and obesity, display a low concentration of $n$ - 3 LC-PUFA in muscle $\mathrm{PL}^{(53)}$. Conversely, insulin sensitivity in obese subjects can be facilitated by the incorporation of DHA in the muscle membrane to a level that may exceed the level found in a lean healthy background population ${ }^{(54,55)}$. This functional association has not been demonstrated in fish yet, although the increased incorporation of DHA in the muscle PL of $\mathrm{R}_{70-}$ ${ }_{20}$ fish can be viewed as part of the complex regulatory mechanisms that orchestrate the change towards energy storage rather than energy mobilisation when nutrient insulin secretagogues become available above a critical threshold level. This type of regulation also operates on a daily basis, and earlier studies in the European sea bass evidenced that the stimulation of feeding behaviour in fish fed at mid-day is accompanied by the phase advancement of circadian insulin rhythms ${ }^{(56)}$. 
Table 6. Effect of feeding ration on the fillet fatty acid (FA) profile of TAG and phospholipids

(\% of total FA methyl esters; mean values and standard deviations of individual fish, $n 9$ )

\begin{tabular}{|c|c|c|c|c|c|c|c|c|c|c|c|c|}
\hline \multirow[b]{3}{*}{ FA } & \multicolumn{6}{|c|}{ TAG (\%) } & \multicolumn{6}{|c|}{ Phospholipids (\%) } \\
\hline & \multicolumn{2}{|c|}{$\mathrm{R}_{100}$} & \multicolumn{2}{|c|}{$\mathrm{R}_{70}$} & \multicolumn{2}{|c|}{$\mathrm{R}_{70-20}$} & \multicolumn{2}{|c|}{$\mathrm{R}_{100}$} & \multicolumn{2}{|c|}{$\mathrm{R}_{70}$} & \multicolumn{2}{|c|}{$\mathrm{R}_{70-20}$} \\
\hline & Mean & SD & Mean & SD & Mean & SD & Mean & SD & Mean & SD & Mean & SD \\
\hline $14: 0$ & 3.60 & $0 \cdot 11$ & 3.63 & 0.19 & 3.69 & $0 \cdot 10$ & $0.94^{\mathrm{a}}$ & 0.12 & $0 \cdot 83^{a, b}$ & $0 \cdot 16$ & $0.75^{\mathrm{b}}$ & 0.09 \\
\hline $16: 0$ & 14.99 & 0.49 & $15 \cdot 05$ & 0.46 & $14 \cdot 72$ & 0.30 & $17 \cdot 31$ & 0.43 & 17.53 & 0.50 & $17 \cdot 33$ & 0.55 \\
\hline $16: 1 n-7$ & $6 \cdot 16$ & 0.15 & $6 \cdot 16$ & 0.09 & 6.25 & 0.11 & $1.55^{\mathrm{a}}$ & 0.12 & $1.50^{\mathrm{a}}$ & 0.14 & $1.22^{\mathrm{b}}$ & 0.10 \\
\hline $16: 2$ & 0.80 & 0.03 & 0.79 & 0.02 & 0.80 & 0.03 & 0.52 & 0.19 & 0.39 & $0 \cdot 12$ & 0.40 & 0.10 \\
\hline $17: 0$ & 0.32 & 0.02 & 0.33 & 0.02 & 0.33 & 0.01 & $0.39^{\mathrm{a}}$ & 0.03 & $0.37^{\mathrm{a}, \mathrm{b}}$ & 0.03 & $0.34^{\mathrm{b}}$ & 0.03 \\
\hline $16: 3$ & 0.76 & 0.29 & 0.85 & 0.12 & 0.76 & 0.31 & 0.15 & 0.07 & 0.19 & 0.14 & 0.13 & 0.05 \\
\hline $16: 4$ & $0.76^{\mathrm{a}}$ & 0.07 & $0.74^{\mathrm{a}, \mathrm{b}}$ & 0.04 & $0.70^{\mathrm{b}}$ & 0.03 & 0.25 & 0.03 & 0.25 & 0.03 & 0.27 & 0.05 \\
\hline $18: 0$ & 3.23 & 0.35 & 3.25 & 0.12 & 3.25 & 0.11 & $7 \cdot 74$ & 0.40 & 7.55 & 0.25 & $7 \cdot 70$ & 0.34 \\
\hline $18: 1 n-9$ & $19 \cdot 00$ & 0.97 & $18 \cdot 84$ & 0.48 & $19 \cdot 10$ & 0.36 & $11.09^{a}$ & 0.33 & $10 \cdot 63^{a, b}$ & 0.82 & $10 \cdot 18^{b}$ & 0.40 \\
\hline $18: 1 n-7$ & $2 \cdot 73$ & 0.18 & $2 \cdot 76$ & 0.07 & 2.83 & 0.07 & $2 \cdot 90^{\mathrm{a}}$ & 0.15 & $2 \cdot 68^{\mathrm{a}, \mathrm{b}}$ & 0.21 & $2 \cdot 63^{\mathrm{b}}$ & 0.04 \\
\hline $18: 2 n-6$ & $19 \cdot 82$ & 0.80 & $19 \cdot 14$ & 0.79 & $19 \cdot 04$ & 0.42 & $12 \cdot 56^{\mathrm{a}}$ & 0.50 & $12 \cdot 09^{\mathrm{a}}$ & 0.51 & $11 \cdot 19^{\mathrm{b}}$ & 0.56 \\
\hline $18: 3 n-6$ & 0.26 & 0.01 & 0.26 & 0.01 & 0.26 & 0.01 & 0.18 & 0.01 & 0.17 & 0.01 & 0.17 & 0.01 \\
\hline $18: 3 n-3$ & 2.29 & 0.20 & 2.17 & $0 \cdot 10$ & $2 \cdot 14$ & 0.05 & $0.82^{\mathrm{a}}$ & 0.04 & $0.76^{\mathrm{b}}$ & 0.06 & $0.62^{c}$ & 0.05 \\
\hline $18: 4 n-3$ & 1.00 & 0.08 & 1.01 & 0.05 & 1.00 & 0.04 & $0.07^{\mathrm{a}}$ & 0.11 & $0.14^{\mathrm{b}}$ & 0.02 & $0.07^{\mathrm{a}}$ & 0.06 \\
\hline $20: 0$ & 0.20 & 0.04 & 0.21 & 0.02 & 0.22 & 0.02 & $0.36^{\mathrm{a}}$ & 0.21 & $0.22^{a, b}$ & 0.06 & $0 \cdot 18^{\mathrm{b}}$ & 0.05 \\
\hline $20: 1 n-7$ & 0.19 & 0.02 & 0.19 & 0.02 & 0.20 & 0.02 & \multicolumn{2}{|c|}{-} & \multicolumn{2}{|c|}{ - } & \multicolumn{2}{|c|}{ - } \\
\hline $20: 1 n-9$ & $1.36^{\mathrm{a}}$ & 0.19 & $1.47^{\mathrm{a}, \mathrm{b}}$ & $0 \cdot 14$ & $1.56^{\mathrm{b}}$ & $0 \cdot 10$ & $0.67^{a}$ & 0.11 & $0.57^{a, b}$ & 0.05 & $0.55^{\mathrm{b}}$ & 0.18 \\
\hline $20: 2 n-6$ & 0.31 & 0.03 & 0.26 & 0.03 & 0.27 & 0.03 & $0.40^{\mathrm{a}}$ & 0.08 & $0.28^{\mathrm{b}}$ & 0.05 & $0.29^{b}$ & 0.08 \\
\hline $20: 3 n-6$ & 0.33 & 0.06 & 0.29 & 0.06 & 0.30 & 0.03 & $0.56^{\mathrm{a}}$ & 0.10 & $0.42^{\mathrm{b}}$ & 0.11 & $0.41^{\mathrm{b}}$ & 0.07 \\
\hline $20: 3 n-3$ & $0 \cdot 10$ & 0.01 & 0.09 & 0.01 & 0.10 & 0.01 & \multicolumn{2}{|c|}{ - } & \multicolumn{2}{|c|}{-} & \multicolumn{2}{|c|}{ - } \\
\hline $20: 4 n-6$ & 0.53 & 0.03 & 0.53 & 0.02 & 0.54 & 0.01 & $2 \cdot 18^{\mathrm{a}}$ & 0.06 & $2 \cdot 32^{\mathrm{a}, \mathrm{b}}$ & 0.21 & $2 \cdot 45^{\mathrm{b}}$ & 0.10 \\
\hline $20: 4 n-3$ & 0.55 & 0.05 & 0.53 & 0.04 & 0.55 & 0.03 & $0.35^{\mathrm{a}}$ & 0.03 & $0.32^{\mathrm{a}, \mathrm{b}}$ & 0.04 & $0.30^{\mathrm{b}}$ & 0.03 \\
\hline $20: 5 n-3$ & 6.33 & 0.49 & $6 \cdot 36$ & 0.35 & $6 \cdot 15$ & 0.21 & $11 \cdot 18^{\mathrm{a}}$ & 0.14 & $11 \cdot 17^{\mathrm{a}, \mathrm{b}}$ & 0.72 & $10 \cdot 49^{\mathrm{b}}$ & 0.57 \\
\hline 22:0 & 0.11 & 0.03 & 0.12 & 0.03 & 0.13 & 0.01 & \multicolumn{2}{|c|}{-} & \multicolumn{2}{|c|}{-} & \multicolumn{2}{|c|}{ - } \\
\hline $22: 1 n-9$ & $0.30^{\mathrm{a}}$ & 0.06 & $0.32^{a, b}$ & 0.04 & $0.34^{\mathrm{b}}$ & 0.03 & \multirow{2}{*}{\multicolumn{2}{|c|}{-}} & \multirow{2}{*}{\multicolumn{2}{|c|}{-}} & \multirow{2}{*}{\multicolumn{2}{|c|}{ - }} \\
\hline $22: 1 n-11$ & 0.85 & 0.21 & 0.97 & $0 \cdot 16$ & 1.03 & 0.12 & & & & & & \\
\hline $22: 5 n-3$ & 2.53 & 0.26 & $2 \cdot 41$ & 0.21 & $2 \cdot 52$ & 0.18 & $3 \cdot 10$ & 0.17 & 2.95 & 0.15 & 3.02 & 0.19 \\
\hline $22: 6 n-3$ & $6 \cdot 48^{\mathrm{a}}$ & 0.19 & $6 \cdot 73^{\mathrm{a}, \mathrm{b}}$ & 0.34 & $6 \cdot 95^{\mathrm{b}}$ & 0.28 & $19 \cdot 17^{\mathrm{a}}$ & 0.45 & $21 \cdot 34^{\mathrm{b}}$ & 1.46 & $23.75^{\mathrm{c}}$ & 1.39 \\
\hline
\end{tabular}

$R_{100}$, full ration until visual satiety; $R_{70}, 70 \%$ of satiation; $R_{70-20}, 70 \%$ of satiation with the last 2 weeks at $20 \%$ of satiation level.

$a, b, c$ Mean values for each lipid class with unlike superscript letters were significantly different $(P<0 \cdot 05)$.

It is well known that PL are first synthesised in the de novo Kennedy pathway ${ }^{(57)}$, but their FA composition at the sn-2 position is altered in the remodelling pathway (Land's cycle) ${ }^{(58)}$ through the concerted action of acyltransferases and phospholipase $\mathrm{A}_{2}$ enzymes. Both biosynthetic pathways have also been described in teleost fish ${ }^{(59,60)}$. The discovery of a number of acyltransferases has recently occurred ${ }^{(61)}$, but it appears that both mammals and fish contain a number of LysoPL acyltransferases that exhibit distinct acyl-CoA and lysoPL acceptor specificities ${ }^{(62)}$. Herein, we focused on LPCAT, given that PC is the principal component of animal cellular membranes ${ }^{(63)}$, and interestingly, the three LPCAT reported in human subjects ${ }^{(64)}$ are represented by the corresponding orthologues (LPCAT1-3) in our gilthead sea bream transcriptome database. Besides, all of them were expressed at detectable levels in the skeletal muscle of gilthead sea bream (LPCAT1 < LPCAT2 < LPCAT3), but none was transcriptionally regulated by ration size in the present experimental model, which limits their role as master regulators of PL FA composition. In this respect, it must also be noted that LPCAT are highly selective for PUFA, but do not discriminate well between $n-6$ PUFA and n-3 PUFA, which would explain, at least in part, why the membrane FA composition of rat skeletal muscle is highly responsive to the balance between $n-6$ and $n$-3 PUFA in the diet ${ }^{(65)}$.
Some other important regulatory steps of PL synthesis and remodelling are the transmethylation reactions catalysed by the PEMT enzyme to convert phosphatidylethanolamine to PC. Of note, cystidine diphosphate choline is the major source of PC under normal physiological conditions but, interestingly, the expression of PEMT is markedly up-regulated in the liver tissue of human subjects and rodents when dietary choline or PC are deficient ${ }^{(66-68)}$. In consequence, as phosphatidylethanolamine unsaturation is generally higher than that of $\mathrm{PC}^{(60,69)}$, a different contribution of cystidine diphosphate choline and PEMT pathways on PC biosynthesis may alter the final composition of plasma membrane PL. Nevertheless, as reported above for LPCAT, the PEMT enzyme was not transcriptionally regulated by severe energy restriction in the present experimental model, which suggests that the observed changes in PL FA composition were more directly related to switches in FA metabolism than PL biosynthesis and remodelling. In that sense, other authors have suggested that PL biosynthesis pathways are limited or inefficient for several fish species (reviewed by Tocher et al. ${ }^{(60)}$ ).

Obviously, one important issue in FA metabolism is the capability for LC-PUFA biosynthesis of different fish species. This has been widely studied in recent years, and a general statement in marine fish, including gilthead sea bream ${ }^{(70)}$, is that the expression of FADS2 ( $\Delta-6$ desaturase) is induced at 

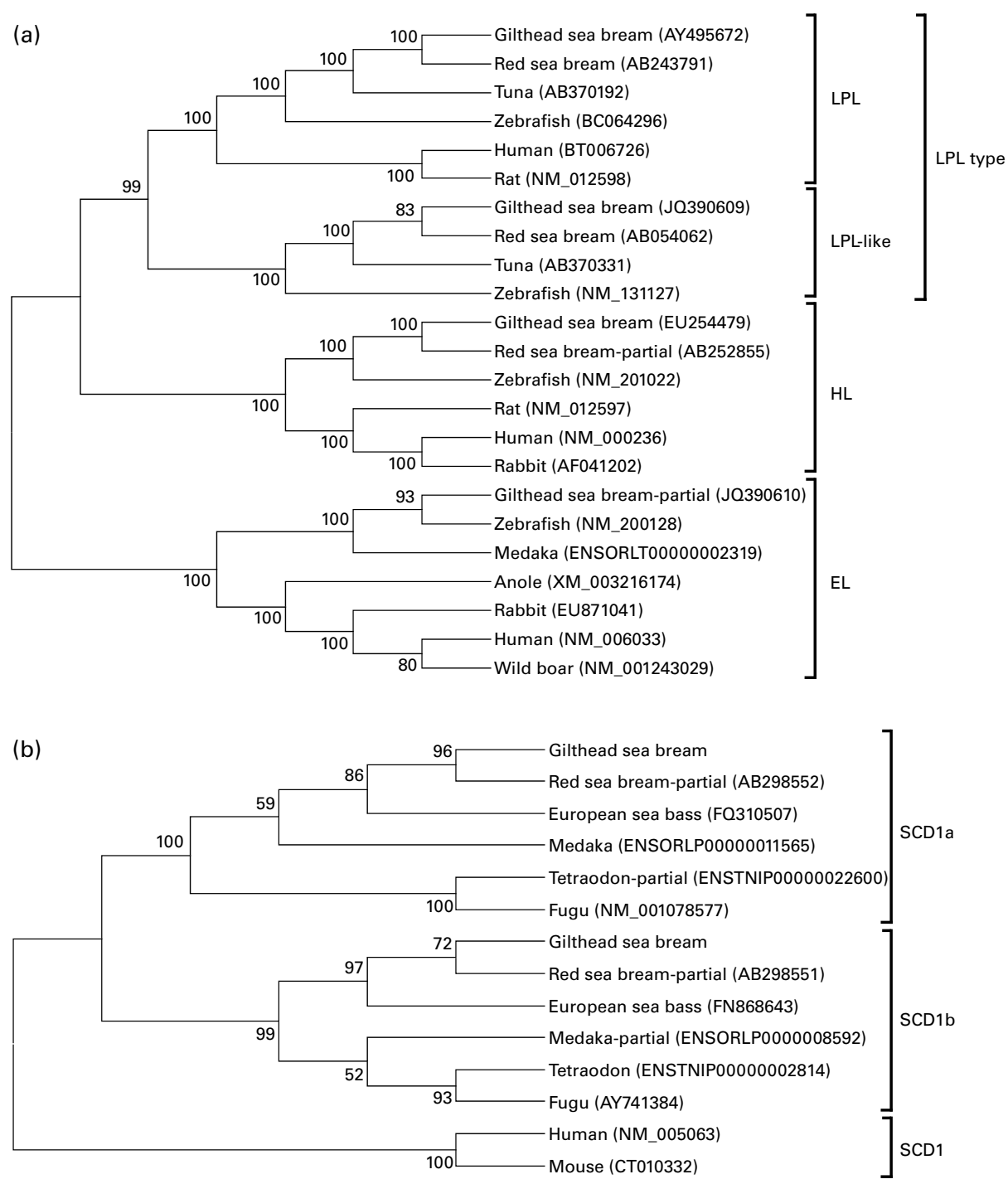

Fig. 2. Phylogenetic analyses of (a) endogenous extracellular TAG lipase family and (b) stearoyl-CoA desaturase 1 family. Bootstrap values are shown at each node. LPL, lipoprotein lipase; LPL-like, lipoprotein lipase-like; HL, hepatic lipase; EL, endothelial lipase; SCD1a, stearoyl-CoA desaturase 1a; SCD1b, stearoylCoA desaturase $b$.

very low levels. This, together with the blockage of $\Delta-5$ desaturase and $\mathrm{C}_{18}-\mathrm{C}_{20}$ elongase steps, greatly limits the flux through LC-PUFA biosynthetic pathways in marine fish ${ }^{(71,72)}$. In the present study, this point of view is reinforced by the reduced mRNA expression of FADS2 in comparison to other analysed transcripts. Additionally, FADS2 was little responsive to changes in ration size; therefore, the enhanced incorporation of LC-PUFA (arachidonic acid and DHA) in muscle PL of $\mathrm{R}_{70-20}$ fish cannot be explained by the enhanced biosynthesis of LC-PUFA.

The SCD enzymes with $\Delta-9$ desaturase activity are ubiquitously found in all living organisms and their mRNA expression, in particular that corresponding to SCD1 enzymes, was highly regulated by ration size in the present experimental model. Major products of SCD activity are palmitoleic acid and oleic acid, but the evolutionary history of these rate-limiting enzymes in the biosynthesis of monoenes is a complex process of duplication and loss events. Thus, as recently reviewed by Castro et al. ${ }^{(28)}$, a different number of paralogous genes (SCD1-SCD5) have been reported in tetrapods and fish. In particular, SCD enzymes have evolved through the evolution of teleost lineage as duplicated genes of SCD1-type (SCD1a, SCD1b), as was further corroborated by the phylogenetic analyses of SCD sequences, including those from gilthead sea bream. From the present results, it is also conclusive that the two SCD isoforms of gilthead sea bream were significantly expressed in the skeletal muscle, although clearly the most abundant mRNA was that codifying for the SCD1b isoform. A different tissue expression level has also been reported in the adipose tissue for the two SCD1 enzymes of red sea bream ${ }^{(73)}$, but regardless of this, the two gilthead sea bream SCD1 isoforms were down-regulated by ration size in the skeletal muscle, which was not surprising given that SCD enzymes are strong markers of lipogenesis in human subjects and rodents and low SCD expression and 

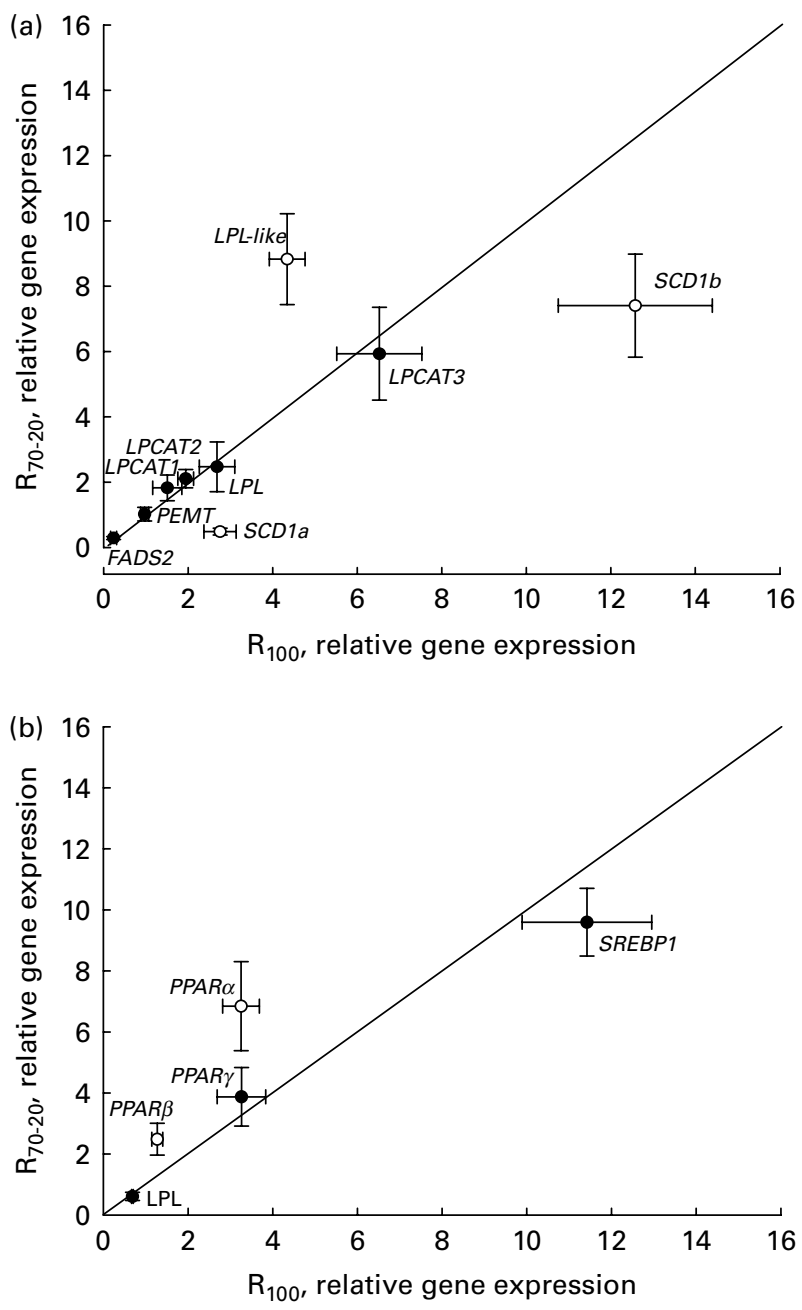

Fig. 3. Relative mRNA expression of (a) lipid enzymes and (b) transcription regulatory factors in the two extreme groups (full ration until visual satiety $\left(R_{100}\right)$ and $70 \%$ of satiation with the last 2 weeks at $20 \%$ of satiation level $\left.\left(\mathrm{R}_{70-20}\right)\right)$ are plotted against each other in the scatter plot. Genes encoding lipoprotein lipase ( $L P L$-like), $P P A R \alpha$ and $P P A R \beta$, are significantly up-regulated $(P<0.05)$ in $\mathrm{R}_{70-20}$ fish. Genes encoding stearoyl-CoA desaturase $1 \mathrm{a}$ (SCD1a) and stearoyl-CoA desaturase 1b (SCD1b) are significantly downregulated $(P<0.05)$ in $\mathrm{R}_{70-20}$ fish. LPCAT1, lysophosphatidylcholine acyltransferase 1; LPCAT2, lysophosphatidylcholine acyltransferase 2; LPCAT3, lysophosphatidylcholine acyltransferase 3; PEMT, phosphatidylethanolamine $\mathrm{N}$-methyltransferase; FADS2, fatty acid desaturase 2; SREBP1, sterol regulatory element-binding protein-1; $L P L \alpha$, lipoprotein lipase $\alpha$.

activity have been associated to a reduced risk of obesity and insulin resistance ${ }^{(74-78)}$

A third means of regulation of tissue FA composition is the endogenous extracellular TAG lipases, which act as keylimiting enzymes on tissue FA uptake. The overall literature strongly supports a distinct regulation of LPL, hepatic lipase and EL, with distinct substrate specificities to accommodate the full spectrum of circulating lipoproteins ${ }^{(79)}$. Hence, LPL displays the highest TAG activity and EL the lowest, whilst at the same time becoming more active as phospholipase ${ }^{(80)}$. The expression of lipases is also tissue specific and EL is synthesised by endothelial cells and by other cell types such as macrophages ${ }^{(81)}$, which agrees with the observation that the gilthead sea bream EL sequence (JQ390610) derived from de novo assembly of next-generation sequencing data contains mostly nucleotide reads from head kidney, the equivalent of bone marrow in mammals. Conversely, the expression of hepatic lipase is restricted to liver (A Saera-Vila and J PérezSánchez, unpublished results), whereas LPL is more ubiquitous, and together with the hormone-sensitive lipase drives the reallocation of body fat depots in fish either with lean phenotypes ${ }^{(26)}$ or with nutritionally mediated changes in lipid storage capacity ${ }^{(25,82)}$. In mammals, it is also well known that fasting down-regulates the LPL activity of adipose tissue $^{(83,84)}$, with no changes or increases in heart and skeletal muscle ${ }^{(85,86)}$. Likewise, fasting decreases LPL activity and mRNA expression in the adipose tissue of gilthead sea bream, which is reversed by either insulin or arginine (potent insulin secretagogue) treatments ${ }^{(87)}$. In the same study, a role of insulin in the regulation of LPL has not been proved in other tissues, which is not surprising given that results from this and previous studies ${ }^{(25,88)}$ highlight a constitutive or low expression of LPL in the white skeletal muscle. In contrast, LPL-like is the predominant LPL isoform in the skeletal muscle of gilthead sea bream and its mRNA expression was markedly up-regulated by the reduction of ration size. Experimental evidence also indicates that LPL transcripts are differentially regulated in the liver tissue of Atlantic salmon in response to diet ${ }^{(89)}$. A different tissue distribution has also been reported for LPL and LPL-like in red sea bream ${ }^{(27)}$, which suggests that, at least in sparid fish, LPL-like is preferentially expressed in muscle tissues in a well-regulated manner. This offers the possibility of a complex tissue regulation that might contribute to modifying the muscle PL FA composition if LPL and LPL-like enzymes actually have distinct TAG and PL activities.

TNF- $\alpha$ is a mediator of insulin resistance, and important studies with TNF- $\alpha$-deficient mice evidenced the improvement of insulin sensitivity in hyperphagic models of rodent obesity $^{(90)}$. In mammals, most of these TNF- $\alpha$-mediated effects are produced by stimulating lipolysis and inhibiting LPL activity at transcriptional and post-transcriptional levels ${ }^{(91)}$. A lipolytic effect of recombinant human TNF- $\alpha$ has been demonstrated in freshly isolated adipocytes of rainbow trout ${ }^{(92)}$ and gilthead sea bream ${ }^{(88)}$ and, interestingly, sequence analysis of the $5^{\prime}$-flanking region of gilthead sea bream LPL reveals a strong conservation of some regulatory elements (GC box, CCAAT/NF-Y, OCT-1) with a synergistic effect on the promoter activity of avian and mammalian $L P L$ genes. Conserved regulatory elements for LXR, PPAR $\alpha$ and SREBP1 have also been reported in the promoter region of SCD enzymes ${ }^{(93)}$, although, unfortunately, SCD promoters remain little studied in fish and in gilthead sea bream, in particular. This makes the interpretation of results arising from upstream regulatory transcriptors more difficult, although it must be noted that $P P A R \alpha$, and also $P P A R \beta$, were responsive to changes in ration size in the present experimental model. In the case of $P P A R \alpha$, its increased mRNA expression with the reduction of ration size is not surprising given that this PPAR isoform has been traditionally associated with lipolytic and SCD-deficient phenotypes $^{(74,78,94)}$. More difficult to explain is the response of 
PPAR $\beta$, but given that this more ubiquitous PPAR isoform has recently been associated to lipogenic rather than lipolytic roles $^{(95,96)}$, the reduced but also stimulated expression of $P P A R \beta$ in $\mathrm{R}_{70-20}$ fish can be viewed as a counter-regulatory response to maintain the muscle lipolytic and lipogenic pathways finely regulated. Indirect evidence for this is provided by the earlier in vitro studies, in which the lipolytic TNF- $\alpha$ cytokine exerts dual effects in primary cultures of gilthead sea bream adipocytes that differ among and between lean and fat fish ${ }^{(26)}$. However, at least in one set of fat fish, the lipolytic effects of TNF- $\alpha$ were apparently mediated by the downregulated expression of $P P A R \beta$.

In summary, a number of new gilthead sea bream sequences (EL, LPL-like, LPCAT, PEMT, SCD1, SREBP1) with important roles in lipid metabolism have been introduced in public database repositories. Additionally, new insights into muscle FA composition and mRNA expression patterns have been addressed in an experimental model of ration size. Interestingly, the results highlight a distinct regulation of FA composition in neutral and polar lipids, which reinforces the concept of the allostatic regulation of PL. From a mechanistic point of view, it is complex to define the vast array of enzymes and upstream regulatory transcriptors that contribute to modify the membrane FA composition, although PPAR, $L P L$-like and SCD1 are emerging as reliable target genes to direct marine fish production and selection towards lean muscle fish phenotypes with increased retentions of LC-PUFA.

\section{Acknowledgements}

The present study was funded by the Spanish MICINN (AQUAFAT, AGL2009-07797, Predictive modelling of flesh FA composition in cultured fish species with different muscle lipid content; AQUAGENOMICS, CSD2007-00002, Improvement of aquaculture production by the use of biotechnological tools) and the European Union (ARRAINA, FP7-KBBE-20115-288925, Advanced research initiatives for nutrition and aquaculture) projects. Additional funding was obtained from the 'GeneralitatValenciana' (research grant PROMETEO 2010/006). G. F. B.-L. was recipient of a Spanish PhD fellowship from the Diputación Provincial de Castellón. The authors are grateful to M. A. González for the excellent technical assistance in PCR analysis. The authors declare that there are no conflicts of interest perceived to bias the study. L. B.-P. performed the FA and phylogenetic analyses; J. A. C.-G. supervised gene expression analyses; G. F. B.-L. was involved in fish culture; and J. P.-S. designed and coordinated the work.

\section{References}

1. Subasinghe R, Soto D \& Jia J (2009) Global aquaculture and its role in sustainable development. Rev Aquacult 1, 2-9.

2. Bell JG, Tocher DR, Henderson RJ, et al. (2003) Altered fatty acid compositions in Atlantic salmon (Salmo salar) fed diets containing linseed and rapeseed oils can be partially restored by a subsequent fish oil finishing diet. J Nutr 133, 2793-2801.

3. Torstensen BE, Froyland L, Ørnsrud R, et al. (2004) Tailoring of a cardioprotective muscle fatty acid composition of
Atlantic salmon (Salmo salar) fed vegetable oils. Food Chem 87, 567-580.

4. Thanuthong T, Francis DS, Senadheera SD, et al. (2011) Fish oil replacement in rainbow trout diets and total dietary PUFA content: I) effects on feed efficiency, fat deposition and the efficiency of a finishing strategy. Aquaculture 320, 82-90.

5. Sargent JR, Tocher DR \& Bell JG (2002) The lipids. In Fish Nutrition, pp. 181-257 [JE Halver and RW Hardy, editors]. San Diego, CA: Academic Press.

6. Benedito-Palos L, Bermejo-Nogales A, Karampatos AI, et al. (2011) Modelling the predictable effects of dietary lipid sources on the fillet fatty acid composition of one-year-old gilthead sea bream (Sparus aurata L.). Food Chem 124, 538-544.

7. Ballester-Lozano GF, Benedito-Palos L, Navarro JC, et al. (2011) Prediction of fillet fatty acid composition of marketsize gilthead sea bream (Sparus aurata) using a regression modelling approach. Aquaculture 319, 81-88.

8. Velázquez M, Zamora S \& Martínez FJ (2006) Effect of different feeding strategies on gilthead sea bream (Sparus aurata) demand-feeding behaviour and nutritional utilization of the diet. Aquac Nutr 12, 403-409.

9. Bonaldo A, Isani G, Fontanillas R, et al. (2010) Growth and feed utilization of gilthead sea bream (Sparus aurata, L.) fed to satiation and restrictively at increasing dietary energy levels. Aquac Int 18, 909-919.

10. Suárez MD, Martínez TF, Saez MI, et al. (2010) Effects of dietary restriction on post-mortem changes in white muscle of sea bream (Sparus aurata). Aquaculture 307, 49-55.

11. Valente LMP, Cornet J, Donnay-Moreno C, et al. (2011) Quality differences of gilthead sea bream from distinct production systems in Southern Europe: intensive, integrated, semiintensive or extensive systems. Food Control 22, 708-717.

12. Kiessling A, Johansson L \& Storebakken T (1989) Effects of reduced feed ration levels on fat content and fatty acid composition in white and red muscle from rainbow trout. Aquaculture 79, 169-175.

13. Kiessling A, Åsgård T, Storebakken T, et al. (1991) Changes in the structure and function of the epaxial muscle of rainbow trout (Oncorbynchus mykiss) in relation to ration and age: III. Chemical composition. Aquaculture 93, 373-387.

14. Kiessling A, Pickova J, Johansson L, et al. (2001) Changes in fatty acid composition in muscle and adipose tissue of farmed rainbow trout (Oncorbynchus mykiss) in relation to ration and age. Food Chem 73, 271-284.

15. Kiessling A, Pickova J, Eales JG, et al. (2005) Age, ration level, and exercise affect the fatty acid profile of chinook salmon (Oncorbynchus tshawytscha) muscle differently. Aquaculture 243, 345-356.

16. Henderson JR \& Tocher DR (1987) The lipid composition and biochemistry of freshwater fish. Prog Lipid Res 26, $281-347$.

17. Los DA \& Murata N (2004) Membrane fluidity and its roles in the perception of environmental signals. Biochim Biophys Acta - Biomembr 1666, 142-157.

18. Ibarz A, Blasco J, Beltran M, et al. (2005) Cold-induced alterations on proximate composition and fatty acid profiles of several tissues in gilthead sea bream (Sparus aurata). Aquaculture 249, 477-486.

19. Folch J, Lees M \& Sloane Stanley GH (1957) A simple method for insolation and purification of total lipides from animal tissues. J Biol Chem 226, 497-509.

20. Olsen RE \& Henderson RJ (1989) The rapid analysis of neutral and polar marine lipids using double-development HPTLC and scanning densitometry. J Exp Mar Biol Ecol 129, 189-197. 
21. Fewster ME, Burns BJ \& Mead JF (1969) Quantitative densitometric thin-layer chromatography of lipids using copper acetate reagent. J Chromatogr 43A 120-126.

22. Christie WW (1982) Lipid Analysis. Isolation, Separation, Identification and Structural Analysis of Lipids. Oxford: Pergamon Press.

23. Calduch-Giner JA, Mingarro M, Vega-Rubín de Celis S, et al. (2003) Molecular cloning and characterization of gilthead sea bream (Sparus aurata) growth hormone receptor (GHR). Assessment of alternative splicing. Comp Biochem Phys 136B, 1-13.

24. Livak KJ \& Schmittgen TD (2001) Analysis of relative gene expression data using real-time quantitative PCR and the $2^{\mathrm{T}-\Delta \Delta \mathrm{CT}}$ method. Methods 25, 402-408.

25. Saera-Vila A, Calduch-Giner JA, Gómez-Requeni $\mathrm{P}$, et al. (2005) Molecular characterization of gilthead sea bream (Sparus aurata) lipoprotein lipase. Transcriptional regulation by season and nutritional condition in skeletal muscle and fat storage tissues. Comp Biochem Phys 142B, $224-232$.

26. Cruz-García L, Saera-Vila A, Navarro I, et al. (2009) Targets for TNF alpha-induced lipolysis in gilthead sea bream (Sparus aurata L.) adipocytes isolated from lean and fat juvenile fish. J Exp Biol 212, 2254-2260.

27. Oku H, Koizumi N, Okumura T, et al. (2006) Molecular characterization of lipoprotein lipase, hepatic lipase and pancreatic lipase genes: effects of fasting and refeeding on their gene expression in red sea bream Pagrus major. Comp Biochem Phys 145B, 168-178.

28. Castro LFC, Wilson JM, Goncalves O, et al. (2011) The evolutionary history of the stearoyl-CoA desaturase gene family in vertebrates. BMC Evol Biol 11, 14.

29. Bermejo-Nogales A, Benedito-Palos L, Calduch-Giner JA, et al. (2011) Feed restriction up-regulates uncoupling protein $3(U C P 3)$ gene expression in heart and red muscle tissues of gilthead sea bream (Sparus aurata L.). New insights in substrate oxidation and energy expenditure. Comp Biochem Phys 159A, 296-302.

30. Wood JD, Enser M, Fisher AV, et al. (2008) Fat deposition, fatty acid composition and meat quality: a review. Meat $\mathrm{Sci}$ 78, 343-358.

31. Kolditz C, Borthaire M, Richard N, et al. (2008) Liver and muscle metabolic changes induced by dietary energy content and genetic selection in rainbow trout (Oncorbynchus mykiss). Am J Physio-Regul Integr Comp Physiol 294, R1154-R1164.

32. Kolditz CI, Paboeuf G, Borthaire M, et al. (2008) Changes induced by dietary energy intake and divergent selection for muscle fat content in rainbow trout (Oncorbynchus mykiss), assessed by transcriptome and proteome analysis of the liver. BMC Genomics 9, 506

33. Bell JG, Pratoomyot J, Strachan F, et al. (2010) Growth, flesh adiposity and fatty acid composition of Atlantic salmon (Salmo salar) families with contrasting flesh adiposity: effects of replacement of dietary fish oil with vegetable oils. Aquaculture 306, 225-232.

34. Benedito-Palos L, Navarro JC, Sitjà-Bobadilla A, et al. (2008) High levels of vegetable oils in plant protein-rich diets fed to gilthead sea bream (Sparus aurata L.): growth performance, muscle fatty acid profiles and histological alterations of target tissues. Br J Nutr 100, 992-1003.

35. Benedito-Palos L, Navarro JC, Kaushik S, et al. (2010) Tissue-specific robustness of fatty acid signatures in cultured gilthead sea bream (Sparus aurata L.) fed practical diets with a combined high replacement of fish meal and fish oil. J Anim Sci 88, 1759-1770.
36. Skalli A \& Robin JH (2004) Requirement of n-3 long chain polyunsaturated fatty acids for European sea bass (Dicentrarchus labrax) juveniles: growth and fatty acid composition. Aquaculture 240, 399-415.

37. Jobling M, Leknes O, Sæther BS, et al. (2008) Lipid and fatty acid dynamics in Atlantic cod, Gadus morbua, tissues: influence of dietary lipid concentrations and feed oil sources. Aquaculture 281, 87-94.

38. Regost C, Arzel J, Cardinal M, et al. (2003) Total replacement of fish oil by soybean or linseed oil with a return to fish oil in Turbot (Psetta maxima): 2. Flesh quality properties. Aquaculture 220, 737-747.

39. Jobling M \& Bendiksen EA (2003) Dietary lipids and temperature interact to influence tissue fatty acid compositions of Atlantic salmon, Salmo salar L., parr. Aquac Res $\mathbf{3 4}$ $1423-1441$

40. Trushenski J, Lewis H \& Kohler C (2008) Fatty acid profile of sunshine bass: II. profile change differs among fillet lipid classes. Lipids 43, 643-653.

41. Schulz C, Knaus U, Wirth M, et al. (2005) Effects of varying dietary fatty acid profile on growth performance, fatty acid, body and tissue composition of juvenile pike perch (Sander lucioperca). Aquac Nutr 11, 403-413.

42. Pettersson A, Pickova J \& Brännäs E (2010) Swimming performance at different temperatures and fatty acid composition of arctic charr (Salvelinus alpinus) fed palm and rapeseed oils. Aquaculture 300, 176-181.

43. Delgado A, Estévez A, Hortelano P, et al. (1994) Analyses of fatty acids from different lipids in liver and muscle of sea bass (Dicentrarchus labrax L.). influence of temperature and fasting. Comp Biochem Phys 108A, 673-680.

44. Kjaer MA, Vegusdal A, Berge GM, et al. (2009) Characterisation of lipid transport in Atlantic cod (Gadus morhua) when fasted and fed high or low fat diets. Aquaculture 288, 325-336.

45. Bendiksen EA \& Jobling M (2003) Effects of temperature and feed composition on essential fatty acid ( $n-3$ and $n-6$ ) retention in Atlantic salmon (Salmo salar L.) parr. Fish Physiol Biochem 29, 133-140.

46. Mourente G \& Bell JG (2006) Partial replacement of dietary fish oil with blends of vegetable oils (rapeseed, linseed and palm oils) in diets for European sea bass (Dicentrarchus labrax L.) over a long term growth study: effects on muscle and liver fatty acid composition and effectiveness of a fish oil finishing diet. Comp Biochem Phy 145B, 389-399.

47. Hansen JØ, Berge GM, Hillestad M, et al. (2008) Apparent digestion and apparent retention of lipid and fatty acids in Atlantic cod (Gadus morbua) fed increasing dietary lipid levels. Aquaculture 284, 159-166.

48. Pratoomyot J, Bendiksen EÅ, Campbell PJ, et al. (2011) Effects of different blends of alternative protein sources as alternatives to dietary fishmeal on growth performance and body lipid composition of Atlantic salmon (Salmo salar L.) Aquaculture 316, 44-52.

49. Storlien LH, Jenkins AB, Chisholm DJ, et al. (1991) Influence of dietary-fat composition on development of insulin resistance in rats - relationship to muscle triglyceride and omega-3-fatty-acids in muscle phospholipid. Diabetes $\mathbf{4 0}$, 280-289.

50. Borkman M, Storlien LH, Pan DA, et al. (1993) The relation between insulin sensitivity and the fatty-acid composition of skeletal-muscle phospholipids. $N$ Engl J Med 328, 238-244.

51. Hu QZ, Ishii E \& Nakagawa Y (1994) Differential changes in relative levels of arachidonic-acid in major phospholipids 
from rat-tissues during the progression of diabetes. J Biochem 115, 405-408.

52. Lombardo YB \& Chicco AG (2006) Effects of dietary polyunsaturated $n-3$ fatty acids on dyslipidemia and insulin resistance in rodents and humans. A review. J Nutr Biochem 17, $1-13$.

53. Pan DA, Lillioja S, Milner MR, et al. (1995) Skeletal muscle membrane lipid composition is related to adiposity and insulin action. J Clin Invest 96, 2802-2808.

54. Haugaard SB, Madsbad S, Hoy CE, et al. (2006) Dietary intervention increases $n$-3 long-chain polyunsaturated fatty acids in skeletal muscle membrane phospholipids of obese subjects. Implications for insulin sensitivity. Clin Endocrinol 64, 169-178.

55. Haugaard SB, Vaag A, Mu HL, et al. (2009) Skeletal muscle structural lipids improve during weight-maintenance after a very low calorie dietary intervention. Lipids Health Dis $\mathbf{8}, 34$.

56. Pérez J, Zanuy S \& Carrillo M (1988) Effects of diet and feeding time on daily variations in plasma-insulin, hepatic camp and other metabolites in a teleost fish, Dicentrarchus labrax L. Fish Physiol Biochem 5, 191-197.

57. Kennedy EP \& Weiss SB (1956) The function of cytidine coenzymes in the biosynthesis of phospholipids. J Biol Chem 222, 193-214.

58. Lands WEM (1958) Metabolism of glycerolipids - comparison of lecithin and triglyceride synthesis. J Biol Chem 231, 883-888.

59. Tocher DR (2003) Metabolism and functions of lipids and fatty acids in teleost fish. Rev Fish Sci 11, 107-184.

60. Tocher DR, Bendiksen E, Campbell PJ, et al. (2008) The role of phospholipids in nutrition and metabolism of teleost fish. Aquaculture 280, 21-34.

61. Hishikawa D, Shindou H, Kobayashi S, et al. (2008) Discovery essential of a lysophospholipid acyltransferase family for membrane asymmetry and diversity. Proc Natl Acad Sci U S A 105, 2830-2835.

62. Tocher DR \& Sargent JR (1992) Direct effects of temperature on phospholipid and polyunsaturated fatty acid metabolism in isolated brain cells from rainbow trout, Oncorbynchus mykiss. Comp Biochem Phys 101B, 353-359.

63. Kazachkov M, Chen QL, Wang LP, et al. (2008) Substrate preferences of a lysophosphatidylcholine acyltransferase highlight its role in phospholipid remodeling. Lipids 43 , 895-902.

64. Pérez-Chacón G, Astudillo AM, Balgoma D, et al. (2009) Control of free arachidonic acid levels by phospholipases $\mathrm{A}_{2}$ and lysophospholipid acyltransferases. Biochim Biophys Acta - Mol Cell Biol Lipids 1791, 1103-1113.

65. Abbott SK, Else PL \& Hulbert AJ (2010) Membrane fatty acid composition of rat skeletal muscle is most responsive to the balance of dietary $n-3$ and $n-6$ PUFA. Br J Nutr 103, 522-529.

66. Cui Z \& Vance DE (1996) Expression of phosphatidylethanolamine $N$-methyltransferase-2 is markedly enhanced in long term choline-deficient rats. J Biol Chem 271, 2839-2843.

67. Browning JD \& Horton JD (2004) Molecular mediators of hepatic steatosis and liver injury. J Clin Invest 114, 147-152.

68. Dong H, Wang J, Li C, et al. (2007) The phosphatidylethanolamine $N$-methyltransferase gene V175M single nucleotide polymorphism confers the susceptibility to NASH in Japanese population. J Hepatol 46, 915-920.

69. Tocher DR (1995) Glycerophospholipid metabolism. Biochem Mol Biol Fishes 4, 119-157.

70. Seiliez I, Panserat S, Corraze G, et al. (2003) Cloning and nutritional regulation of a $\Delta 6$-desaturase-like enzyme in the marine teleost gilthead seabream (Sparus aurata). Comp Biochem Phys 135B, 449-460.

71. Tocher DR, Zheng X, Schlechtriem C, et al. (2006) Highly unsaturated fatty acid synthesis in marine fish: cloning, functional characterization, and nutritional regulation of fatty acyl Delta 6 desaturase of Atlantic cod (Gadus morhua L.). Lipids 41, 1003-1016.

72. Zheng X, Ding Z, Xu Y, et al. (2009) Physiological roles of fatty acyl desaturases and elongases in marine fish: characterisation of cDNAs of fatty acyl $\Delta 6$ desaturase and elovl5 elongase of cobia (Rachycentron canadum). Aquaculture 290, 122-131.

73. Oku H \& Umino T (2008) Molecular characterization of peroxisome proliferator-activated receptors (PPARs) and their gene expression in the differentiating adipocytes of red sea bream Pagrus major. Comp Biochem Phys 151B, 268-277.

74. Ntambi JM, Miyazaki M, Stoehr JP, et al. (2002) Loss of stearoyl-CoA desaturase-1 function protects mice against adiposity. Proc Natl Acad Sci U S A 99, 11482-11486.

75. Dobrzyn A \& Dobrzyn P (2006) Stearoyl-CoA desaturase - a new player in skeletan muscle metabolism regulation. $J$ Physiol Pharmacol 57, 31-42.

76. Hulver MW, Berggren JR, Carper MJ, et al. (2005) Elevated stearoyl-CoA desaturase-1 expression in skeletal muscle contributes to abnormal fatty acid partitioning in obese humans. Cell Metab 2, 251-261.

77. Jiang GQ, Li ZH, Liu F, et al. (2005) Prevention of obesity in mice by antisense oligonucleotide inhibitors of stearoyl-CoA desaturase-1. J Clin Invest 115, 1030-1038.

78. Sampath H \& Ntambi JM (2006) Stearoyl-coenzyme A desaturase 1 , sterol regulatory element binding protein-1c and peroxisome proliferator-activated receptor-alpha: independent and interactive roles in the regulation of lipid metabolism. Curr Opin Clin Nut. Metab Care 9, 84-88.

79. Wong H \& Schotz MC (2002) The lipase gene family. J Lipid Res 43, 993-999.

80. McCoy MG, Sun GS, Marchadier D, et al. (2002) Characterization of the lipolytic activity of endothelial lipase. J Lipid Res 43, 921-929.

81. Yasuda T, Hirata KI, Ishida T, et al. (2007) Endothelial lipase is increased by inflammation and promotes LDL uptake in macrophages. J Atheroscler Thromb 14, 192-201.

82. Cruz-García L, Sánchez-Gurmaches J, Bouraoui L, et al. (2011) Changes in adipocyte cell size, gene expression of lipid metabolism markers, and lipolytic responses induced by dietary fish oil replacement in gilthead sea bream (Sparus aurata L.). Comp Biochem Phys 158A, 391-399.

83. Lladó I, Pons A \& Palou A (1999) Effects of fasting on lipoprotein lipase activity in different depots of white and brown adipose tissues in diet-induced overweight rats. J Nutr Biochem 10, 609-614.

84. Bergo M, Olivecrona G \& Olivecrona T (1996) Forms of lipoprotein lipase in rat tissues: in adipose tissue the proportion of inactive lipase increases on fasting. Biochem $J \mathbf{3 1 3}$, 893-898.

85. Sugden MC, Holness MJ \& Howard RM (1993) Changes in lipoprotein-lipase activities in adipose-tissue, heart and skeletal-muscle during continuous or interrupted feeding. Biochem J 292, 113-119.

86. Ruge T, Svensson M, Eriksson JW, et al. (2005) Tissuespecific regulation of lipoprotein lipase in humans: effects of fasting. Eur J Clin Invest 35, 194-200.

87. Albalat A, Saera-Vila A, Capilla E, et al. (2007) Insulin regulation of lipoprotein lipase (LPL) activity and expression in gilthead sea bream (Sparus aurata). Comp Biochem Phys 148B, 151-159. 
88. Saera-Vila A, Calduch-Giner JA, Navarro I, et al. (2007) Tumour necrosis factor (TNF) $\alpha$ as a regulator of fat tissue mass in the Mediterranean gilthead sea bream (Sparus aurata L.). Comp Biochem Phys 146B, 338-345.

89. Morais S, Edvardsen RB, Tocher DR, et al. (2012) Transcriptomic analyses of intestinal gene expression of juvenile Atlantic cod (Gadus morhua) fed diets with Camelina oil as replacement for fish oil. Comp Biochem Phys 161B, 283-293.

90. Ventre J, Doebber T, Wu M, et al. (1997) Targeted disruption of the tumor necrosis factor-alpha gene - metabolic consequences in obese and nonobese mice. Diabetes 46, 1526-1531.

91. Bulló-Bonet $\mathrm{M}$, García-Lorda $\mathrm{P}$, López-Soriano $\mathrm{FJ}$, et al. (1999) Tumour necrosis factor, a key role in obesity? FEBS Lett 451, 215-219.

92. Albalat A, Gómez-Requeni P, Rojas P, et al. (2005) Nutritional and hormonal control of lipolysis in isolated gilthead seabream (Sparus aurata) adipocytes. A J Physiol-Regul Integr Comp Physiol 289, R259-R265.

93. Mauvoisin D \& Mounier C (2011) Hormonal and nutritional regulation of SCD1 gene expression. Biochimie 93, 78-86.

94. Miyazaki M, Flowers MT, Sampath H, et al. (2007) Hepatic stearoyl-CoA desaturase-1 deficiency protects mice from carbohydrate-induced adiposity and hepatic steatosis. Cell Metab 6, 484-496.

95. Barak Y, Liao D, He WM, et al. (2002) Effects of peroxisome proliferator-activated receptor delta on placentation, adiposity, and colorectal cancer. Proc Natl Acad Sci U S A 99, 303-308.

96. Peters JM, Lee SST, Li W, et al. (2000) Growth, adipose, brain, and skin alterations resulting from targeted disruption of the mouse peroxisome proliferator-activated receptor beta(delta). Mol Cell Biol 20, 5119-5128. 